\title{
Evaluation of paclobutrazol application method on quality characteristics of ornamental pepper ${ }^{(1)}$
}

\author{
CHRISTIANE DE FÁTIMA MARTINS FRANÇA ${ }^{(2)}$, LUCAS CAVALCANTE DA COSTA ${ }^{(3)^{*}}$ \\ WELLINGTON SOUTO RIBEIRO(3), TERESA DRUMMOND CORREIAMENDES ${ }^{(3)}$, \\ MIRELLE NAYANA DE SOUSA SANTOS(4), FERNANDO LUIZ FINGER(3)
}

\begin{abstract}
The effects of three paclobutrazol (PBZ) application methods on ornamental characteristics of two pepper cultivars ('Biquinho Vermelha' and 'Bode Amarela') were evaluated. Plant growth regulator at $10 \mu \mathrm{M} \mathrm{PBZ}$ was added at transplanting by drenching $250 \mathrm{~mL}$ PBZ solution on the pot substrate, foliar spray of $10 \mathrm{~mL}$ PBZ solution or by submerging seedlings root + substrate for 10 seconds in the PBZ solution. Control plants were treated with tap water applied directly on the substrate. Plant height, canopy compactness, fruits and leaves number, and leaf chlorophyll content were evaluated when $50 \%$ of the plants had approximately $30 \%$ of mature fruits (commercial maturity). PBZ applied by drenching influenced positively the ornamental characteristics of 'Bode Amarela'. Otherwise, the best PBZ application method for 'Biquinho Vermelha' was not established. The results suggest that search for suitable PBZ application method that no affects the pepper ornamental characteristics must be done specifically for each pepper cultivar.
\end{abstract}

Keywords: Capsicum chinense, growth, chlorophyll content, canopy, plant growth regulator.

\section{RESUMO}

Avaliação do método de aplicação do paclobutrazol sobre as características de qualidade de pimenteira ornamental Três métodos de aplicação do paclobutrazol (PBZ) foram avaliados com base nos efeitos sobre as características que conferem a qualidade ornamental de duas cultivares de pimenteira ('Biquinho Vermelha' e 'Bode Amarela'). A solução de PBZ, na concentração de $10 \mu \mathrm{M}$, foi adicionada na ocasião do transplantio por meio da aplicação de $250 \mathrm{~mL}$ de solução de PBZ diretamente no substrato de cultivo, pulverização das folhas com $10 \mathrm{~mL}$ da solução de PBZ, ou por meio do molhamento do conjunto raiz + substrato da muda por 10 segundos na solução de PBZ. Nas plantas controle, foram aplicados $250 \mathrm{~mL}$ de água diretamente no substrato de cultivo. A altura das plantas, compacidade da copa, número de frutos, número de folhas e o teor de clorofila das folhas foram avaliados quando $50 \%$ das plantas de cada tratamento apresentaram aproximadamente $30 \%$ de frutos maduros (maturidade comercial). A aplicação direta de paclobutrazol no substrato de cultivo mostrou-se o método mais adequado para a manutenção das características ornamentais da 'Bode amarela'. Em contrapartida, o melhor método de aplicação de PBZ para a 'Biquinho Vermelha' não foi estabelecido. Os resultados sugerem que a busca pelo modo e concentração adequados para a obtenção de qualidade na pós-produção de pimenteira ornamental devem ser estudados especificamente para cada cultivar de pimenteira.

Palavras-chave: Capsicum chinense, crescimento, conteúdo de clorofila, copa, regulador de crescimento.

\section{INTRODUCTION}

Ornamental pepper grown as potted plant has expanded considerably in Brazil and the world (COSTA et al., 2015; MUTLU et al., 2015). Some cultivars of the Capsicum genus which have ornamental quality characteristics such variegated foliage, small size, uniform canopy formation and strong coloring fruits are rather used as ornamental plants (REGO et al., 2009). In this vein, the paclobutrazol (PBZ) growth regulator has been widely used for adapting tall plants to dwarf ornamental plant (AHMAD et al., 2015; MUTLU et al., 2015; BOSCH et al., 2016). However, PBZ efficacy greatly depends on active ingredient, volume of solution, humidity and composition of substrate (CURREY and LOPEZ, 2009). Likewise, the plant development stage, product concentration of the product, specie, cultivar and application method significantly influence the efficiency in providing the quality characteristics of ornamental potted plants (AHMAD et al., 2015; BOSCH et al., 2016).

In general, PBZ is applied directly on the soil or potting substrate (drench), however it is known that variation among species and cultivars to growth regulators may

\footnotetext{
DOI: http://dx.doi.org/10.14295/oh.v23i3.1074

${ }^{(1)}$ Received in 01/07/2017 and accepted in 25/09/2017

(2)Universidade Federal do Oeste da Bahia (UFOB), Barra-BA, Brazil.

${ }^{(3)}$ Universidade Federal de Viçosa (UFV), Departamento de Fitotecnia, Viçosa-MG, Brazil. *Corresponding author: costalc@ymail.com

${ }^{(4)}$ Universidade Federal de Viçosa (UFV), Departamento de Biologia Vegetal, Viçosa-MG, Brazil.

Licensed by CC BY 4.0
} 
occur (CURREY and LOPEZ, 2009). Although PBZ can be applied by foliar spray, the compound is poorly soluble in water and consequently little translocated in the phloem. Thus, when applied by spray to the plant canopy, its action is restricted to the wet contact area (RIBEIRO et al., 2011). On the other hand, the application of PBZ by drench is uniform and increases the product efficiency in lower concentrations compared to foliar spray. Therefore, we evaluated three paclobutrazol application methods, based on the effect on growth, crown compactness, number of fruits and leaves, and leaf chlorophyll content of two ornamental pepper cultivars.

\section{MATERIAL AND METHODS}

Capsicum chinense Bode Amarela and Biquinho Vermelha cultivars were evaluated in this trial. Seeding was sown in polystyrene trays filled with commercial Bioplant ${ }^{\circledR}$ substrate, composed by peel of Pinus, coconut fiber, vermiculite, rice husk and nutrients. The PBZ at $10 \mu \mathrm{M}$ was applied at transplanting using three different methods: direct drenching $250 \mathrm{~mL}$ PBZ solution on pot substrate, foliar spray with $10 \mathrm{~mL}$ of PBZ solution, and seedlings root + substrate immersion for 10 seconds in the PBZ solution. In the control plants, $250 \mathrm{~mL}$ of water were applied directly on the substrate. The seedlings presented two or three pairs of leaves transplanted into a $900 \mathrm{~mL}$ pot (11 cm high, $9.5 \mathrm{~cm}$ basal diameter, $13.5 \mathrm{~cm}$ upper diameter), containing the same substrate used for sowing. Plants were grown in greenhouse conditions under $28 \pm 2$ ${ }^{\circ} \mathrm{C}$, relative humidity $65 \pm 5 \%$ and light intensity of 500 $\mu \mathrm{mol}$ of photons $\mathrm{m}^{-2} \mathrm{~s}^{-1}$. At planting, the substrate was fertilized with $2.5 \mathrm{~g}$ of the formulated NPK 0-10-10 (side dressing was not performed). Irrigation was conducted once or twice daily as needed. Plant height, canopy compactness, fruits number, leaves number and leaves chlorophyll content were evaluated when $50 \%$ plants in each treatment presented approximately $30 \%$ of mature fruits (commercial maturity).
Plant height was taken from the substrate level to top of the plant (the last fully expanded leaf). The ratio between the longitudinal and transverse direction lengths of the plant aerial part was used to determine the canopy compactness according to following criterion: circular canopies present values closer to one (1). Total number of fruits and leaves of each plant was determined at commercial maturity. Chlorophyll content (SPAD index) was estimated by SPAD-502 chlorophyll meter (Spectrum Technologies Inc., Plainfield, IL) with the average of nine leaves which represented three leaves of each part of the plant (basal, medial and superior part). Experiments were carried out in a completely randomized design with five replicates of individual pots. Variance analysis was performed by comparison of means by the Tukey test at $5 \%$ error probability for each cultivar using the $\mathrm{R}$ version 3.3.0 program (R Foundation for Statistical Computing, Vienna, Austria).

\section{RESULTS AND DISCUSSION}

Substrate drenching and root + substrate immersion methods significantly inhibited the growth of both ornamental pepper cultivars (Table 1). When root + substrate immersion method was used, the 'Bode Amarela' and 'Biquinho Vermelha' heights were lower in 86.2 and $93 \%$, respectively, as compared to control plants. Indeed, when the application of the growth regulator was done by drenching, the heights of 'Bode Amarela' and 'Biquinho Vermelha' were, respectively, 62.8 and $85.7 \%$ lower than the control plants (Table 1). In this case, the drench method reduced the 'Bode Amarela' height with no toxicity or dwarfism effects. On the other hand, 'Biquinho Vermelha' showed symptoms of dwarfism as a consequence of the PBZ solution application by drench method, making it unviable to commercialize as ornamental plants. In addition, the plants from PBZ application method by root + substrate immersion presented smaller stem elongation and toxicity symptoms, such as brittle and puckering leaves.

Table 1. Plant height (PH), total leaves number (LN) and chlorophyll content (CC) in response to application methods of $10 \mu \mathrm{M}$ PBZ in two ornamental pepper cultivars ('Biquinho Vermelha' and 'Bode Amarela')

\begin{tabular}{|c|c|c|c|c|c|c|}
\hline \multirow{2}{*}{ Method } & \multicolumn{9}{|c}{ Cultivars } \\
\cline { 2 - 7 } & \multicolumn{3}{|c|}{ Bode Amarela } & \multicolumn{3}{c|}{ Biquinho Vermelha } \\
\hline & PH $(\mathbf{c m})$ & LN & CC (SPAD index) & PH (cm) & LN & CC (SPAD index) \\
\hline Control & $58.8 \mathrm{a}$ & $100 \mathrm{a}$ & $28.7 \mathrm{c}$ & $34.9 \mathrm{a}$ & $119.2 \mathrm{a}$ & $41.5 \mathrm{~b}$ \\
\hline Spray & $54.2 \mathrm{a}$ & $100.4 \mathrm{a}$ & $37.6 \mathrm{c}$ & $33.0 \mathrm{a}$ & $118.4 \mathrm{a}$ & $43.2 \mathrm{~b}$ \\
\hline Drench & $21.9 \mathrm{~b}$ & $127.8 \mathrm{a}$ & $53.6 \mathrm{~b}$ & $8.4 \mathrm{~b}$ & $67.5 \mathrm{~b}$ & $65.9 \mathrm{a}$ \\
\hline Root + substrate & $8.1 \mathrm{c}$ & $40.8 \mathrm{~b}$ & $81.9 \mathrm{a}$ & $4.1 \mathrm{~b}$ & $42.0 \mathrm{~b}$ & $72.4 \mathrm{a}$ \\
\hline
\end{tabular}

Means followed by the same lower case letter in the column do not differ statistically by Tukey's test at 5\% error probability.

Although application methods affected plant height and leaves number and it did not affect crown compactness. Our results also showed significant effect of the application method on total fruits number. Only root + substrate immersion in the PBZ solution method differs from the control, which inhibited completely fruit formation (data not shown). It might explained because gibberellic acid biosynthesis promoted by PBZ may cause delay in 
flowering and consequently less or none fruits production (RADEMACHER, 2000). Differently, when applied as foliar spray in Consolida orientalis, the increase in the concentration of PBZ was accompanied by higher flowers numbers (MANSORUGLU et al., 2009), which shows high variation among species. When PBZ was applied by root + substrate immersion, the leaves number was reduced compared to control plants on both cultivars. For 'Biquinho Vermelha', the PBZ application by drenching also reduced the number of leaves in relation to control, and had any difference in comparison to root + substrate immersion method (Table 1). In contrast, 'Bode Amarela' did not show reduction in the number of leaves when compared to control, giving positive value as ornamental plant.

The treated plants leaves with PBZ by both root + substrate immersion in the solution or drench methods presented higher chlorophyll concentration in relation to chlorophyll concentration in control plants leaves (Table 1). In addition to providing a suitable size for ornamental pot plant, the PBZ also favors the development of greener leaves, which is a desirable feature for an ornamental plant. Darker green leaves were also observed in the orchids Consolida orientalis and Arundina graminifolia treated with foliar spray and drench PBZ application method respectively, and 'Pitanga' pepper plants by both, foliar spray and drench PBZ application (MANSUROGLU et al., 2009; WANDERLEY et al., 2014; GROSSI et al., 2005). In this context, Berova and Zlatev (2000) reported that enhances in chlorophyll content is attributed to increases in phytyl content, which it is generated by the same terpenoid pathway as gibberellins. Hence, since PBZ inhibits the biosynthesis of gibberellins, provides the use of gibberellin synthesis intermediates, facilitating increased phytyl production (BELAKBIR, 1998; KUMAR et al., 2012), which has resulted in higher chlorophyll content and dark green color as observed in our ornamental pepper plants treated with PBZ.

On the other hand, the PBZ application method by foliar spray had no effect on none of the evaluated variables when compared to control, being an inadequate method of PBZ application method for peppers cultivars tested in this work. This fact is related to the nature of this plant growth regulator, which presents little solubility in water, making it impossible to translocate via phloem, acting only on contact area (RIBEIRO et al., 2011). Differently, studying Physalis growth regulation by PBZ, Bosch et al. (2016) found appropriate plant size for use as an ornamental by both foliar spray and drench methods. However, the concentration of PBZ for foliar spray was 94\% higher than used in drench method.

\section{CONCLUSIONS}

The PBZ at $10 \mu \mathrm{M}$ by drench method at time of transplanting was effective in maintaining the ornamental characteristics on 'Bode Amarela' pepper plant, being therefore a PBZ application method indicated for this cultivar. However, the appropriate PBZ application method for 'Biquinho Vermelha' could not be established, suggesting that the evaluation of the method of application as well as the ideal concentration should be determined for each pepper cultivar. In addition, the foliar spray method is not recommended for both cultivars studied.

\section{REFERENCES}

AHMAD, I.; DOLE, J.M.; WHIPKER, B.E. Paclobutrazol or uniconazole effects on ethylene sensitivity of potted ornamental plants and plugs. Scientia Horticulturae, v.192, p.350-356, 2015. DOI: <http://dx.doi.org/10.1016/j. scienta.2015.04.032>

BELAKBIR A. Yield and fruit quality of pepper (Capsicum annum L.) in response to bioregulators. HortScience, v.33, p.85-87, 1998.

BEROVA, M.; ZLATEV Z. Physiological response and yield of paclobutrazol treated tomato plants (Lycopersicon esculentum Mill.). Plant Growth Regulation, v.30, p.117-123, 2000. DOI: <http://dx.doi. org/10.1023/A:1006300326975>

BOSCH, E.; CUQUEL, F.L.; TOGNON, G.B. Physalis size reduction for potted ornamental plant use. Ciência e Agrotecnologia, v.40, n.5, p.555-564, 2016. DOI: <http:// dx.doi.org/10.1590/1413-70542016405031716>

COSTA, L.C.; RIBEIRO, W.S.; PINTO, C.M.F.; SILVA, F.C.; FINGER, F.L. Quality of ornamental pepper grown in different substrates. Acta Horticulturae, n.1060, 243-248, 2015. DOI: <http://dx.doi.org/10.17660/ ActaHortic.2015.1060.36>

CURREY C.J.; LOPEZ R.G. Applying plant growth retardants for height control. In: Commercial greenhouse and nursery production. Purdue: Purdue Extension, 2009. 10p.

GROSSI, J.A.S.; MORAES P.J.; TINOCO S.A.; BARBOSA J.G.; FINGER F.L.; CECON P.R. Effects of paclobutrazol on growth and fruiting characteristics of 'Pitanga' ornamental pepper. Acta Horticulturae, v.683, p.333-336, 2005. DOI: <http://dx.doi.org/ 10.17660/ ActaHortic.2005.683.41>

KUMAR, S.; GHATTY, S.; SATYANARAYANA, J.; GUHA, A. CHAITANYA, B.; REDDY, A.R. Paclobutrazol treatment as a potential strategy for higher seed oil yield in field-grown Camelina sativa L. Crantz. BMC Researsch Notes, v.5, p.137-149, 2012.

MANSUROGLU, S.; KARAGUZEL, O.; ORTACESME, V.; SAYAN, M.S. Effect of paclobutrazol on flowering, leaf and flower colour of Consolida orientalis. Pakistan Journal of Botany, v.41, p.2323-2332, 2009.

MUTLU, S.S.; AGAN, E. Effects of paclobutrazol and pinching on ornamental pepper. HortTechnology, v.25, n.5, 657-664, 2015. 
R CORE TEAM. R: A language and environment for statistical computing. $\mathrm{R}$ Foundation for Statistical Computing, Vienna, Austria, 2016. Available at: https:// www.R-project.org/ Accessed on: Setember $26^{\text {th }} 2017$.

RÊGOE.R.; RÊGO, M.M.; SILVA, D.F.; SANTOS, R.M.C.; SAPUCAY, M.J.L.C.; SILVA, D.R.; SILVA JÚNIOR, S.J. Selection for leaf and plant size and longevity of ornamental peppers (Capsicum spp.) grown in greenhouse condition. Acta Horticulturae, v.829, p.371-375, 2009. DOI: <http:// dx.doi.org/10.17660/ActaHortic.2009.829.59>
RIBEIRO D.M.; MULLER, C.; BEDIN, J.; ROCHA, G.B.; BARROS, R.S. Effects of autoclaving on the physiological action of paclobutrazol. Agricultural Science, v.2, p.191-197, 2011. DOI: <http://dx.doi.org/10.4236/ as.2011.23026>

WANDERLEY, C.D.S.; FARIA, R.T.D.; VENTURA, M.U.; VENDRAME, W. The effect of plant growth regulators on height control in potted Arundina graminifolia orchids. Acta Scientiarum, v.36, p.89-494, 2014. DOI: <http:// dx.doi.org/10.4025/actasciagron.v36i4.18085> 